\title{
Study of Disease Pattern among Personnel Deployed in Mali focusing on Pre-Deployment Health Preparedness
}

\author{
Hasan $\mathrm{MA}^{1}$, Jahan $\mathrm{S}^{2}$ \\ DOI: https://doi.org/10.3329/jafmc.v17i1.56715
}

\begin{abstract}
Introduction: Demographic and epidemiological transition has altered disease patterns globally. Adequate knowledge on disease patterns will provide scope for pre-deployment health preparedness. Providing important information regarding disease patterns, correct diagnosis of a disease and its management contribute in effective patient care system.
\end{abstract}

Objective: To find out the pattern of disease existing in level-I hospital of the UN peacekeepers in Mali.

Materials and Methods: This cross-sectional analytical study was carried out in the Level-I Hospital for the period of 01(one) year from 1st July 2018 to 30th June 2019. Sample size was 2193. Data were collected from the patients reported sick in the hospital during the specified period. All patients are divided in two categories; Outdoor patients and Indoor patients. We have classified the diseases into four broad categories: (1) Injury, (2) Non-infectious Diseases, (3) Infectious Diseases and (4) Sexually Transmitted Infections. All the collected data were edited and analyzed.

Results: Disease patterns in the level-I hospital of UN peacekeepers are not the same as per the disease prevalence of Mali.Disease patterns in UN peacekeeper mainly includes musculoskeletal low back pain, Peptic Ulcer Disease, Dry eye syndrome, Upper Respiratory Tract infections, Diarrheal diseases, Urinary tract infections and Malaria.

Conclusion: Pre-deployment health education to the UN peacekeeper including the healthcare services provider contributes to the positive influence on health. Pre-deployment health training should be focused on disease patterns occurring in Level-I hospital, at the same time prevalence of diseases of the specific country has to be taken into account.

Key-words: Disease patterns, Disease prevalence, Level-I hospital, Health preparedness.

\section{Introduction}

Since the early 1990s, there has been a significant increase in the number of peacekeeping missions under the auspices of the United Nations (UN). Mali is one of the many countries in which the UN is tasked to support a peace process. Bangladesh started its UN Peace Keeping Operations (PKOs) in Mali since 2014. They need to work in the North-East part of the country Sector-East, Gao region which belongs to the Sub-Saharan and Saharan hot semi-arid climate.

Demographic and epidemiological transition has altered disease patterns globally. Since the geographical alteration and inadequate experience of working in an adverse environment, UN peacekeeper has to face lot of challenges during performing duties. Keeping these facts in consideration. the present study has been planned to define the patterns of disease occurrence in level-I hospital of Mali mission area. Adequate knowledge on disease patterns will provide scope for pre-deployment health preparedness to increase efficiency of UN peacekeepers. Moreover, this type of study has not done yet before. Data regarding the disease patterns in level-I hospitals are not adequate.

\section{Materials and Methods}

This cross-sectional analytical study was carried out in the Level-I Hospital of BANBAT (Bangladesh Infantry Battalion), Sector East (MINUSMA) in Gao super camp, Mali for the period of 01(one) year from 1st July 2018 to 30th June 2019. Sample size was 2193. Data were collected from the patients reported sick in the hospital during the specified period.

Two types of persons reported in the hospitals which are (1) UN military and (2) UN Nonmilitary local staff. All patients are divided in two categories, Outdoor patients and Indoor patients. Data on outdoor patients defined as visit to the OPD wing, take medicine after consultation with physician and not an over-night stay. Indoor patients were defined as an overnight stay in the hospital anytime in a reference period of 365 days.

For analytical purposes, we have classified the diseases into four broad categories. Which are (1) Injury - which includes Weapons or Mine injury, Road Traffic Accident, Sports or recreational and work related injury, (2) Non Infectious diseases - which includes

1. Lt Col Md Amirul Hasan, MBBS, MS (CV\&TS), Classified Specialist in Surgery, Senior Medical Officer (SMO), Level-I Hospital, BANBAT-6, MINUSMA, Mali 2. Maj Sharmin Jahan, MBBS, MPH, MPhil (PSM), DADH, Army Head Quarters, Med Dte.

\begin{tabular}{lll}
\hline 18$)$ & JAFMC Bangladesh. Vol 17, No 1 (June) 2021
\end{tabular} 
Cardiovascular, Pulmonary, Gastrointestinal, Musculoskeletal, Neurological, Eye, ENT, Skin, Tumor or Neoplasm, (3) Infectious diseases - which includes Upper respiratory, Pulmonary TB, Gastroenteritis, Malaria, Hepatitis, Dengue, Urogenital, Meningitis, Skin infections and others non specific, (4) Sexually Transmitted Infections - which includes Gonorrhea, Syphilis, HIVIAIDS and others. This classification is done according to the Report-returns format sent to the higher HQ on weekly and monthly basis.

\section{Results}

Total 2193 patients attended in the hospital OPD in 01 year. Maximum patients attended in September (294), October (218) and November (236). Minimum patients were attended in the months of February (122) and July (124) (Table-I). Regarding category of OPD patients, UN Military were 1192 (54.4\%) and UN Civilian were 1001 (45.7\%) (Figure-1). Figure-2 shows disease wise distribution of OPD patients. Out of the total patients Noninfectious diseases were the highest (66.7\%). Others were Infectious diseases (18.7\%) and Injury (14.6\%). No STD patient was reported in the OPD. Figure-3 shows distribution of total non infectious disease $(n=1463)$ of OPD patients. Out of the total non infectious diseases Musculoskeletal 403 (27.6\%), Eye 219 (15\%) and GIT 187(12.8\%) were the highest and Cardiovascular 45(3.1\%) were the lowest. Out of the total infectious diseases most patients were suffering from Upper Respiratory Tract infections 196(47.7\%), followed by GIT infections $121(29.4 \%)$ and Urogenital infections 88(21.4\%) (Table-II). Out of the total 229 patients Noninfectious 124 (54.2\%) patients were the highest and Injury 31 $(13.5 \%)$ patients were the lowest. No STD infection patient was admitted (Table-III). Out of 74 admitted infectious disease patients, Upper respiratory infection 41 (55.4\%) and Malaria 18 (24.3\%) patients were the highest (Table-IV).

Table-I: Month wise distribution of total OPD patients $(n=2193)$

\begin{tabular}{|l|c|c|c|}
\hline \multicolumn{1}{|c|}{ Month } & $\begin{array}{c}\text { UN } \\
\text { Military }\end{array}$ & $\begin{array}{c}\text { UN } \\
\text { Nonmilitary }\end{array}$ & $\begin{array}{c}\text { Total } \\
\text { Patients }\end{array}$ \\
\hline July & 78 & 46 & 124 \\
\hline August & 95 & 106 & 201 \\
\hline September & 125 & 169 & 294 \\
\hline October & 84 & 134 & 218 \\
\hline November & 112 & 124 & 236 \\
\hline December & 103 & 63 & 166 \\
\hline January & 115 & 76 & 191 \\
\hline February & 64 & 58 & 122 \\
\hline March & 116 & 46 & 162 \\
\hline April & 97 & 38 & 135 \\
\hline May & 127 & 33 & 160 \\
\hline June & 76 & 108 & 184 \\
\hline Total & 1192 & 1001 & $\mathbf{2 1 9 3}$ \\
\hline
\end{tabular}

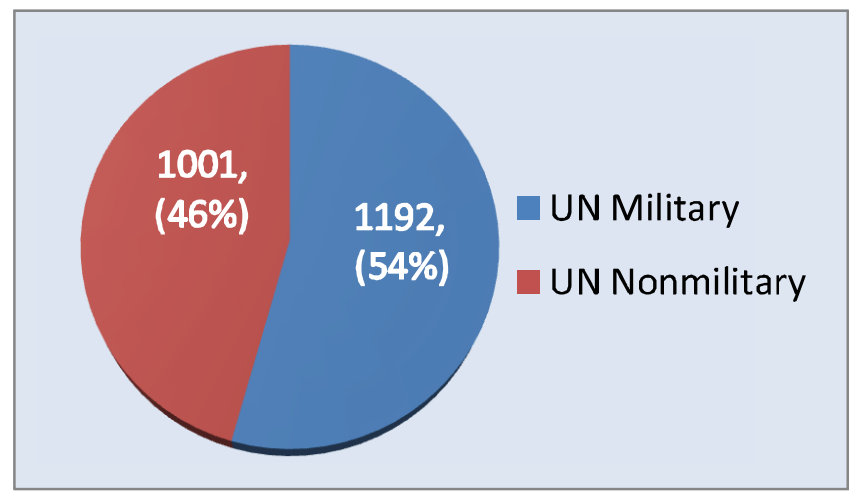

Figure-1: Distribution of category of total OPD patients $(n=2193)$

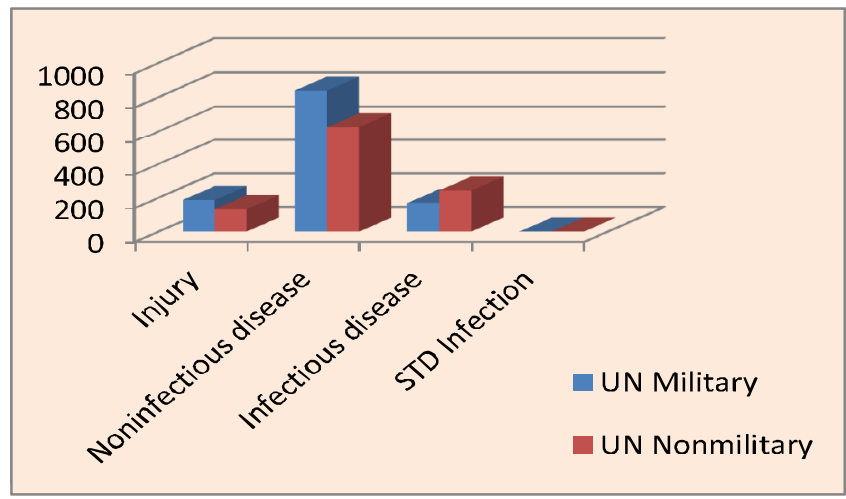

Figure-2: Disease wise distribution OPD patients(n=2193)

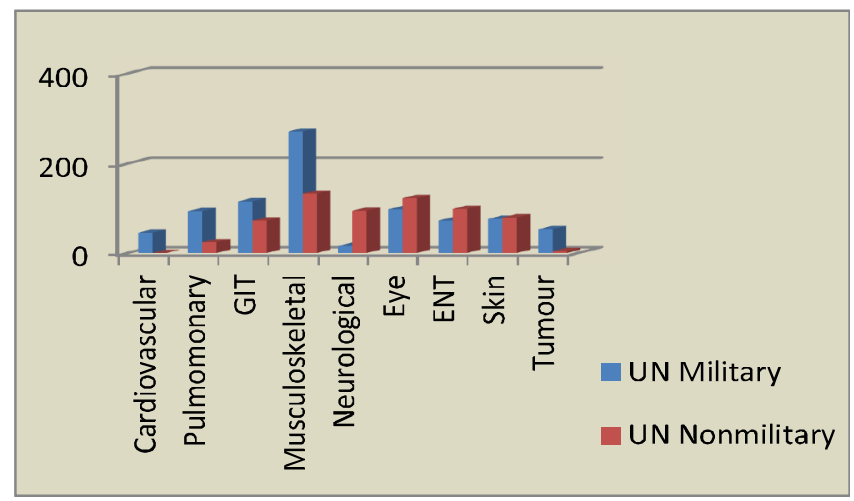

Figure-3: Distribution of Non-infectious disease of OPD patients $(n=1463)$

Table-II: Distribution of Infectious disease of OPD patients $(n=411)$

\begin{tabular}{|l|c|c|c|c|}
\hline \multicolumn{1}{|c|}{ Category } & $\begin{array}{c}\text { UN } \\
\text { Military }\end{array}$ & $\begin{array}{c}\text { UN } \\
\text { Nonmilitary }\end{array}$ & $\begin{array}{c}\text { Total } \\
\text { Patients }\end{array}$ & $\begin{array}{c}\% \text { of Total } \\
\text { Patients }\end{array}$ \\
\hline $\begin{array}{l}\text { Upper } \\
\text { Respiratory }\end{array}$ & 115 & 81 & 196 & 47.7 \\
\hline Pulmonary TB & 0 & 0 & - & - \\
\hline GIT & 26 & 95 & 121 & 29.4 \\
\hline Malaria & 01 & 0 & 01 & 0.2 \\
\hline Hepatitis & 01 & 0 & 01 & 0.2 \\
\hline Dengue & 0 & 0 & - & - \\
\hline Urogenital & 21 & 67 & 88 & 21.4 \\
\hline Meningitis & 0 & 0 & - & - \\
\hline Skin infections & 04 & 0 & 04 & 1 \\
\hline Total & 168 & $\mathbf{2 4 3}$ & $\mathbf{4 1 1}$ & $100 \%$ \\
\hline
\end{tabular}


Table-III: Disease wise distribution Indoor patients in 01 year $(n=229)$

\begin{tabular}{|l|c|c|c|c|}
\hline \multicolumn{1}{|c|}{ Category } & $\begin{array}{c}\text { UN } \\
\text { Military }\end{array}$ & $\begin{array}{c}\text { UN } \\
\text { Nonmilitary }\end{array}$ & $\begin{array}{c}\text { Total } \\
\text { Patients }\end{array}$ & $\begin{array}{c}\% \text { of Total } \\
\text { Patients }\end{array}$ \\
\hline Injury & 31 & - & 31 & 13.5 \\
\hline $\begin{array}{l}\text { Noninfectious } \\
\text { disease }\end{array}$ & 124 & - & 124 & 54.2 \\
\hline $\begin{array}{l}\text { Infectious } \\
\text { disease }\end{array}$ & 74 & - & 74 & 32.3 \\
\hline STD Infection & - & - & - & - \\
\hline Total & 229 & - & 229 & $100 \%$ \\
\hline
\end{tabular}

Table-IV: Distribution of Infectious disease of Indoor patients $(n=74)$

\begin{tabular}{|l|c|c|c|c|}
\hline \multicolumn{1}{|c|}{ Category } & $\begin{array}{c}\text { UN } \\
\text { Military }\end{array}$ & $\begin{array}{c}\text { UN } \\
\text { Nonmilitary }\end{array}$ & $\begin{array}{c}\text { Total } \\
\text { Patients }\end{array}$ & $\begin{array}{c}\% \text { of Total } \\
\text { Patients }\end{array}$ \\
\hline $\begin{array}{l}\text { Upper } \\
\text { Respiratory }\end{array}$ & 41 & 0 & 41 & 55.4 \\
\hline Pulmonary TB & 0 & 0 & 0 & 0 \\
\hline GIT & 09 & 0 & 09 & 12.2 \\
\hline Malaria & 18 & 0 & 18 & 24.3 \\
\hline Hepatitis & 0 & 0 & 0 & 0 \\
\hline Dengue & 0 & 0 & 0 & 0 \\
\hline Urogenital & 02 & 0 & 02 & 2.7 \\
\hline Meningitis & 04 & 0 & 04 & 5.4 \\
\hline Skin infections & 0 & 0 & 0 & 0 \\
\hline Total & 74 & 0 & 74 & $100 \%$ \\
\hline
\end{tabular}

\section{Discussion}

Bangladesh with more than 6,000 uniformed personnel is one of the top suppliers of UN peacekeepers and has been so over the past three decades ${ }^{1}$. Bangladesh deployed UN peacekeeping personnel in Mali where they are tasked to support a peace process, protect civilians from violence, and help build sustainable peace. The Republic of Mali is a landlocked country bordered by 07 countries of largest in western Africa, situated between the Tropic of Cancer and the Equator. The country spans three major climatic zones. A large central band of semi-arid, sub-Saharan climate, where rain falls only from mid-June to October. Due to the expansion of the desert region or 'desertification', rainfall is negligible in the Sahara desert. Bangladesh UN peacekeepers need to work in the part of the country which belongs to the Sub-Saharan and Saharan hot semi-arid climate.

The study was carried out in the Level-I Hospitalin Gao super camp, Mali for the period of 01(one) year from 1st July 2018 to 30th June 2019. Outdoor and Indoor patients Data were collected reporting sick in the hospital during the specified period.

The result shows that in 01 year total 2193 patients have been reported in the OPD to seek medical assistance. Most of the patients were reported in September (294), October (218) and November (236). Similarly most of the patients were admitted in September(30), October(24), November(25) and December(22). There is single rainy season from July to October, followed by a long dry season of 8-9 months. During and after the rainy season, various diseases are more prevalent especially fever caused mainly by Malaria².

Out of the total OPD and indoor patients Noninfectious diseases were the highest (66.7\% and 54.2\%) followed by Infectious disease (18.7\% and $32.3 \%$ ) and Injury (14.6\% and $13.5 \%)$. There is no STD infection in OPD and indoor patients, thoughHIVIAIDS continues to be one of the top diseases in Mali. For Malians, between the ages of 15 and 49, HIVIAIDS accountable for 13 percent of all deaths ${ }^{3}$.

Among the non-infectious diseases Musculoskeletal, GIT and Eye cases were the highest. Non traumatic low back pain was one of main causes of musculoskeletal disease. UN peacekeeping mission in Mali is most challenging and deadliest than any other since it dealt with ambushes, complex attacks, and other asymmetric and terrorist tactics, such as suicide attacks and improvised explosive devices (IEDs) ${ }^{4}$.To combat these situation peacekeepers need to be alert always with bulletproof jacket, helmet and heavy weapons for long period of time. This causes to report in OPD frequently for musculoskeletal low back pain.

In noninfectious GIT disease patients mainly reported with Peptic Ulcer Disease (PUD). Irregular food habit and stress from peculiar duty pattern may be the contributing factors. The major causes of eye diseases in Mali are cataracts (29.2\%), glaucoma (22.9\%), trachoma (14.6\%), ocular manifestations linked to HIVIAIDS (8.3\%), and non-glaucomatous optical neuropathies (8.3\%)5. Trachoma as a blinding disease is found in all regions of the country $^{5}$. But most of the eye patients reported in Level-I with Dry eye syndrome (Keratitis sicca or Keratoconjunctivitissicca). In Mali there is semi-arid, sub-Saharan climate, where rain falls is minimum with extreme low humidity causing dryness of air ${ }^{6}$. This causes dry eye syndrome in UN peacekeeper.

In infectious diseases most patients were Upper Respiratory (47.7\%), GIT (29.4\%) and Urogenital (21.4\%) infections. In Mali Respiratory Infections especially common cold, sinusitis, pharyngitis and bronchitis are found to be particularly dangerous caused by a virus, called respiratory syncytial virus (RSV), but can also be spread by bacteria and fungus ${ }^{6}$.

In GIT infections diarrheal diseases are responsible for an estimated one in every seven deaths in Mali6. Diarrheal diseases are found to originate from contaminated food and insufficient water sources ${ }^{6}$. Urinary tract infections are quite common in the peacekeeper due to inadequate intake of drinking water.

Total 18 patients are admitted in the hospital due to Malaria in one year period. $90 \%$ of the Malian population was labeled as having a high transmission (more than 1 case per 1000 people) of malaria. Malaria is the primary cause of mortality in Mali, responsible for 19 percent of all deaths ${ }^{6}$. Occurrence of malaria is much less in UN peacekeeper in comparison to disease prevalence of malaria in 
Mali. This is mainly due to various Anti Malarial preventive measures, Malaria prophylaxis medications and adequate awareness among the troops.

In Mali infectious skin diseases are $41 \%$ of all diagnoses, which includes mainly scabies, superficial mycoses, primary pyoderma, dermatitis?. In this hospital total skin disease patients (11.3\%) are not significant in comparison to skin disease prevalence in Mali mostly because of short term staying in Mali.

From the above discussion it is postulated that disease patterns in the level-I hospital of UN peacekeepers are not the same as per the disease prevalence of Mali. In Mali the most common food or waterborne diseases include Diarrhoea (bacterial and protozoal), Hepatitis and typhoid fever. Malaria and dengue fever is also very common. Mali is endemic with all five major Neglected Tropical Diseases (NTDs) which include lymphatic filariasis (LF), onchocerciasis, schistosomiasis, soil-transmitted helminthiasis (STH, including ascariasis, hook-worm infection and trichuriasis) and trachoma ${ }^{8}$. In Mali an estimated $1.3 \%$ of adult Malians lived with HIV infections ${ }^{9}$. Human Q-fever is found sero-prevalence of $24 \%$ in healthy urban people occurring by drinking contaminated raw milk ${ }^{10}$.

Demographic and epidemiological transition have altered disease pattern globally. But the disease patterns in UN peacekeeper are different which mainly includes musculoskeletal low back pain, Peptic Ulcer Disease, Dry eye syndrome, Upper Respiratory Tract infections, Diarrheal diseases, Urinary tract infections and Malaria.

No such study on disease patterns is carried out earlier. This study provides important baseline data regarding disease patterns in the hospital. Given the contexts mentioned above, the present study aims to find out the major health impediments facing by the Bangladesh UN peace keepers and thereby suggesting and recommending to train and prepare them at all level for deployment to ensure the successful participation.

\section{Conclusion}

The security situation in Mali is highly volatile with considerable potential for violence which makes it most challenging than any other UN peacekeeping missions. Bangladesh's participation in UN peacekeeping missions has been widely applauded at home and abroad. Appropriate health capacity development from adequate knowledge on disease patterns of the peacekeepers is a significant component on the successful participation in such mission.
Predeployment health education to the UN peacekeeper including the healthcare services provider contributes to the positive influence on health. Predeployment health training should be focused on disease patterns occurring in Level-I hospital, at the same time prevalence of diseases of the specific country has to take into account. It is worth to conduct a detailed research in this regard. However in spite of having greater importance it is hard to find out any substantial research work on the disease patterns for health preparedness of participation UN peacekeepers.

\section{References}

1. Jacob M, Kathman D and Melin M. Who Keeps the Peace? Understanding State Contributions to UN Peacekeeping Operations. International Studies Quarterly. 2016; 10:1093/isq/sqw041.

2. Alassane D, Carsten M, Boureima $\mathrm{K}$ et al. Season, fever prevalence and pyrogenic threshold for malaria disease definition in an endemic area of Mali. Tropical Medicine and International Health. 2005; 10(6):550-6.

3. Jordan JP. Top Diseases in Mali: The Impact \& Possible Solutions. BorgenmagazineGlobal Health October, 2016; Available at https://wwww.borgenmagazine.com/impact-solutions-top-diseases -in-mali/

4. John K, Adam C, Smith M. Europe's Return to UN Peacekeeping in Africa? Lessons from Mali. New York International Peace Institute. 2015; 7:11-2.

5. Eballe AO, Boitte JP, Traore J. Ocular disorders causing blindness in working-age outpatients: A prospective study at the African Institute of Tropical Ophthalmology (IOTA, Bamako, Mali). Sante Montrouge France. 2005; 15(4):241-5.

6. Sangare O, Dungu B, Bastos AD. Foot and mouth disease in Mali: The current situation and proposed control strategies. RSTOI Epiz. 2004; 23(3):863-72.

7. Mahe A, Cisse IA, Faye $O$ et al. Skin diseases in Bamako (Mali).International Journal of Dermatology.1998; 37:673-6.

8. Dembele M, Bamani S, Dembele R et al. National Neglected Tropical Disease Control Program in Mali. PLoS Negl Trop Dis. 2012; 6(3):e1574.

9. Riddick J. Preventing Common Diseases in Mali. Borgen magazine Global Health August, 2017; https://borgenproject. org/common-diseases-in-mali/

10. Steinmann $\mathrm{P}$, Bonfoh B, Peter $\mathrm{O}$ et al. Seroprevalence of Q-fever in febrile individuals in Mali.Tropical Medicine and International Health. 2005; 10(6):612-7. 